\title{
Seleksi Penerima Beasiswa Dengan Metode Fuzzy Multi-Attribute Decision Making Dengan Pengembangan
}

\author{
Receiver Selection with Fuzzy Multi-Attribute Decision Making With Development Method \\ ${ }^{1,2}$ Program Studi Sistem Informasi, Fakultas Teknologi Informasi, Universitas Mercu Buana \\ Yogyakarta, Jl. Wates Km. 10 Yogyakarta 55753, Indonesia \\ Email: markmonemnasi04@gmail.com, anief@mercubuana-yogya.ac.id
}

\begin{abstract}
ABSTRAK
Beasiswa merupakan pemberian berupa bantuan keuangan yang diberikan kepada perorangan bertujuan untuk digunakan demi keberlangsungan pendidikan. Bantuan ini dapat diberikan oleh lembaga pemerintahan, perusahaan atau yayasan. Sekolah Menengah Atas Tiga Maret (SMA GAMA) Yogyakarta memiliki program pemberian beasiswa kepada siswa miskin atau kurang mampu di sekolah tersebut. Akan tetapi dalam melakukan seleksi beasiswa tersebut mengalami banyak kesulitan karena proses seleksinya masih manual serta banyaknya siswa yang mengajukan dan banyaknya kriteria yang digunakan sehingga dalam proses penentuannya menyita waktu yang banyak.

Oleh karena itu diperlukan sebuah sistem yang membantu, mempercepat dan mempermudah pihak yang bersangkutan dalam proses seleksinya. Proses pengambil keputusan dibangun menggunakan metode fuzzy multi-attribute decision making. Metode ini akan membantu pengambil keputusan pada situasi dimana terdapat banyak alternatif keputusan dengan beberapa kriteria. Dipilihnya fuzzy multi-attribute decision making karena karakternya sangat tepat untuk menyelesaikan permasalahan yang semi-terstruktur seperti masalah beasiswa ini, juga merupakan metode yang akan cukup akurat memberikan hasil yang diharapkan serta akan mampu juga mengurangi kesalahan-kesalahan proses seleksi dan mempercepat proses pengambilan keputusannya.

Hasil akhir dari sistem yang dibuat berupa rekomendasi penerima beasiswa dengan nilai total tertinggi dimana sebelumnya sistem akan melakukan perhitungan dan seleksi dari data yang telah dimasukan yang selanjutnya akan diurutkan dari nilai total integral tertinggi hingga nilai total integral terendah sehingga pengguna dapat dengan mudah menentukan siapa yang berhak dan layak untuk menerima beasiswa dan yang paling sesuai dengan kriteria yang telah ditetapkan.
\end{abstract}

Kata kunci: Sistem Pendukung Keputusan, Beasiswa, Fuzzy, FMADM

\begin{abstract}
The scholarship is a gift in the form of financial aid given to individuals intended to be used for the sake of continuing education. This assistance can be provided by government agencies, companies or foundations. High School Three March (SMA GAMA) Yogyakarta has a scholarship program for poor or underprivileged students in the school. However, in the selection of scholarships are experiencing many difficulties because the selection process is still manual and the number of students who filed and the number of criteria used so that in the process of determining time consuming a lot.

Therefore required a system that helps, accelerate and facilitate the parties concerned in the selection process. The decision process is built using the fuzzy multi-attribute decision making method. This method will help decision makers in situations where there are many alternative decisions with multiple criteria. The choice of fuzzy multi-attribute decision making because its character is very appropriate to solve semi-structured problems such as this scholarship problem, is also a method that will be quite accurate to give the expected results and will also be able to reduce the selection process mistakes and accelerate the decision-making process.

The final result of the system made in the form of the scholarship recomendation with the highest total value where previously the system will perform the calculation and selection of the data that has been entered which will then be sorted from the highest total integral value to the lowest integral total value so that the user can easily determine who is entitled and is eligible to receive the scholarship and that best fits the established criteria.
\end{abstract}

Keywords: Decision Support System, Scholarship, Fuzzy, FMADM 


\section{PENDAHULUAN}

Beasiswa adalah bantuan material yang diberikan oleh instansi atau lembaga kepada seseorang yang memenuhi syarat sebagai penerima beasiswa. Beasiswa pendidikan, salah satu jenis beasiswa yang perlu perhatian khusus karena mempunyai pengaruh besar dalam pemerataan kesempatan pendidikan. SMA Tiga Maret Yogyakarta adalah salah satu sekolah swasta di Yogyakarta yang memiliki program beasiswa bagi siswa-siswi miskin atau kurang dalam hal perekonomian. Namun dalam proses penentuan penerima beasiswa tersebut memakan waktu yang cukup lama dikarenakan proses seleksi yang masih manual.

Beasiswa adalah pemberian berupa bantuan keuangan yang diberikan kepada perorangan yang bertujuan untuk digunakan demi keberlangsungan pendidikan yang ditempuh. Beasiswa juga merupakan bantuan untuk membantu orang yang masih sekolah atau kuliah agar mereka dapat menyelesaikan tugasnya dalam rangka mencari ilmu pengetahuan hingga selesai. Beasiswa dapat diberikan oleh lembaga pemerintah, perusahaan ataupun yayasan. Beasiswa pendidikan, salah satu jenis beasiswa yang perlu perhatian khusus karena mempunyai pengaruh besar dalam pemerataan kesempatan pendidikan. Bantuan ini biasanya berbentuk dana untuk menunjang biaya atau ongkos yang harus dikeluarkan oleh anak sekolah atau mahasiswa selama menempuh masa pendidikan di tempat belajar yang diinginkan (Murniasih, 2009).

Rumusan permasalahan dalam penelitian ini antara lain : (1) Bagaimana perancangan database pada sistem pengambil keputusan seleksi penerima beasiswa? (2) Bagaimana perancangan antarmuka (interface) pada sistem pengambil keputusan seleksi penerima beasiswa? (3) Bagaimana pemodelan dan implementasi fuzzy logic pada sistem pengambil keputusan seleksi penerima beasiswa?

Adapun tujuan dari penelitian ini adalah untuk mendesain dan membangun sebuah prototype sistem pengambil keputusan dalam seleksi penerima beasiswa dengan metode fuzzy multi-attribute decision making.

Manfaat dari sistem informasi yang dibuat adalah sebagai alat atau perangkat lunak yang diharapkan dapat membantu kerja tim penyeleksi dalam proses penyeleksian atau penentuan penerima beasiswa sehingga mendapatkan hasil yang akurat terhadap siapa yang layak untuk menerima beasiswa sehingga mempercepat proses penentuan dan mengurangi kesalahan yang didapat saat penentuan secara manual.

\section{TINJAUAN PUSTAKA}

Beberapa penelitian yang terkait seperti pada penelitian mengenai penentuan penerimaan beasiswa dengan menggunakan fuzzy multiple attribute decision making yang digunakan untuk membantu penentuan pengambilan keputusan untuk kelayakan penerima beasiswa terutama di perguruan tinggi. Pada penelitian ini, output yang dihasilkan adalah urutan alternatif mulai dari yang tertinggi ke alternatif terendah. Hasil akhir diperoleh dari nilai setiap kriteria, karena didalam kriteria memiliki bobot nilai yang berbeda. Alternatif yang dimaksud adalah mahasiswa calon penerima beasiswa (Putra \& Hardiyanti, 2011).

Selanjutnya penelitian mengenai mengenai pengambil keputusan penerima BOP pendidikan madrasah menggunakan metode fuzzy multi-criteria decision making. Pada penelitian ini, menghasilkan keluaran berupa program komputer dengan Software Borland Delphi 7 dalam sistem pendukung keputusan yang dapat memberikan sebuah proses nilai akhir yang lebih akurat dan cepat (Suhendar \& Novia, 2014).

Selanjutnya dalam penelitian yang dengan menggunakan metode Fuzzy Multi Decision Making (FMADM) dan Simple Additive Weighting (SAW) dalam menentukan rekomendasi penerima beasiswa. Metode FMADM digunakan untuk mencari alternatif dari sejumlah alternatif dengan kriteriakriteria yang telah ditentukan. Sedangkan Metode SAW digunakan untuk merangking dari alternatif yang ada. Hasil penelitian ini dapat digunakan sebagai alat bantu dalam mengambil keputusan untuk merekomendasikan penerima beasiswa (Surya, 2015).

Selajutnya dalam penelitian untuk penentuan supplier yang menggunakan 9 kriteria sebagai parameter penilaian, metode yang digunakan Fuzzy Multiple Attribute 
Decision Making (FMADM) dan Simple Additive Weighting (SAW). Berdasarkan hasil perhitungan baik metode perusahaan maupun sistem memberikan hasil yang serupa (Harjayanti \& Rozi, 2016).

Selain itu penelitian serupa yang menggunakan FMADM dan SAW juga digunakan untuk penentuan pilihan program studi yang menggunakan kriteria berdasarkan nilai akhir ujian nasional. Hasil dari penelitian ini dari penggunaan metode POLTEKES Permata Indonesia Yogyakarta maupun menggunakan sistem metode FMADM dengan SAW memiliki hasil 76,92\% yang sesuai dan 23,08\% data yang tidak sesuai dari 26 data dalam pemilihan program studi (Priatni \& Purnomo, 2017).

Fuzzy Multiple Attribute Decision Making (FMADM) adalah suatu metode yang digunakan untuk mencari alternatif optimal dari sejumlah alternatif dengan kriteria tertentu. Inti dari FMADM adalah menentukan bobot untuk setiap atribut, kemudian dilanjutkan dengan proses perangkingan yang akan menyeleksi alternatif yang sudah diberikan. Pada dasarnya, ada 3 pendekatan untuk mencari nilai bobot atribut, yaitu pendekatan subyektif, pendekatan obyektif, dan pendekatan integrasi antara subyektif dan obyektif. Masing-masing pendekatan memiliki kelebihan dan kelemahan. Pada pendekatan subyektif, nilai bobot ditentukan berdasarkan subyektifitas dari para pengambil keputusan, sehingga beberapa faktor dalam proses perangkingan alternatif bisa ditentukan secara bebas. Sedangkan pada pendekatan obyektif, nilai bobot dihitung secara matematis sehingga mengabaikan subyektifitas dari pengambil keputusan (Kusumadewi, et al., 2006).

\section{METODOLOGI PENELITIAN}

Secara garis besar proses jalannya penelitian ini dibagi menjadi empat tahapan, yaitu : (1) Inteligensi, (2) Desain, (3) Pemilihan, dan (4) Implementasi dan solusi. Selanjutnya jalannya penelitian dapat dilihat pada Gambar 1.

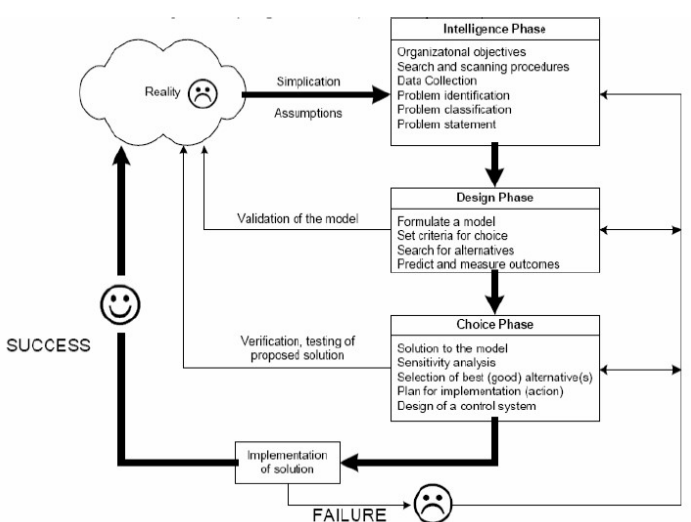

Gambar 1. Desain Sistem (Turban, et al., 2005)

\subsection{Inteligensi}

Pada fase ini, realitas diuji, dan masalah diidentifikasi dan ditentukan. Kepemilikan masalah juga ditetapkan. Intelegensi mencakup berbagai identifikasi situasi atau peluang-peluang masalah (Turban, et al., 2005). Struktur hierarki permasalahan dapat dilihat pada Gambar 2.

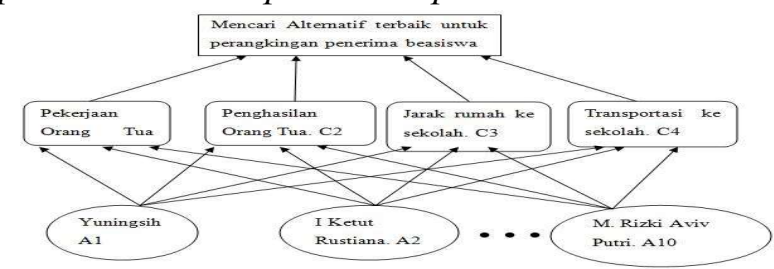

Gambar 2. Struktur Hieraki Masalah

\subsection{Desain}

Fase desain meliputi penemuan atau mengembangkan dan menganalisis tindakan yang mungkin untuk dilakukan. Hal ini meliputi pemahaman terhadap masalah dan menguji solusi yang layak. Sebuah model masalah pengambil keputusan dikonstruksi, dites, dan divalidasi (Turban, et al., 2005).

Dalam penyelesaian kasus pada penelitian ini, berikut langkah-langkah yang dilakukan:

1. Menentukan kriteria yang digunakan untuk acuan pengambilan keputusan, yaitu : C1 Pekerjaan Orang Tua, C2 = Penghasilan Orang Tua, C3 = Jarak rumah ke Sekolah, Transportasi ke Sekolah.

2. Standar fuzzyfikasi dari masing-masing kriteria penilaian yang digunakan dalam sistem, seperti pada Tabel 1. 
Tabel 1. Fuzzyfikasi

\begin{tabular}{|c|c|c|c|c|}
\hline & Kriteria 1 & Kriteria 2 & Kriteria 3 & Kriteria 4 \\
\hline & Orang tua siswa & Penghasilan orang & Jarak dari rumah & Siswa ke sek \\
\hline $\begin{array}{l}\text { Sangat } \\
\text { Bagus }\end{array}$ & $\begin{array}{l}\text { tidak memiliki } \\
\text { pekerjaan yang } \\
\text { tetap. }\end{array}$ & $\begin{array}{ll}\text { tua } & < \\
1.000 .000 . & R p .\end{array}$ & $\begin{array}{l}\text { ke sekolah lebih } \\
\text { dari } 3 \mathrm{KM} \text {. }\end{array}$ & \\
\hline Bagus & $\begin{array}{l}\text { Pekerjaan orang } \\
\text { tua sebagai petani } \\
\text { atau pedagang. }\end{array}$ & $\begin{array}{l}\text { Penghasilan orang } \\
\text { tua berkisar antara } \\
\text { Rp. } 1.000 .000-R p \text {. } \\
2.000 .000\end{array}$ & $\begin{array}{l}\text { Jarak rumah ke } \\
\text { sekolah kurang } \\
\text { lebih 2-2.99 KM }\end{array}$ & $\begin{array}{l}\text { Siswa ke sekolah } \\
\text { menggunakan } \\
\text { transportasi umum. }\end{array}$ \\
\hline Cukup & $\begin{array}{l}\text { Orang tua siswa } \\
\text { bekerjar sebagai } \\
\text { buruh swasta atau } \\
\text { padar suatu } \\
\text { perusahan. }\end{array}$ & $\begin{array}{l}\text { Penghasilan orang } \\
\text { tua dikisaran } \\
\text { Rp.2.000.000-Rp. } \\
3.000 .000 .\end{array}$ & $\begin{array}{l}\text { Jarak rumah ke } \\
\text { sekolah kurang } \\
\text { lebih 1-1.99 KM. }\end{array}$ & $\begin{array}{l}\text { Siswa ke sekolah } \\
\text { diantar oleh orang } \\
\text { tua atau keluarga } \\
\text { menggunakan } \\
\text { transportasi pribadi. }\end{array}$ \\
\hline Rendah & $\begin{array}{l}\text { Orang tua siswa } \\
\text { bekerja dalam } \\
\text { sektor formal atau } \\
\text { sebagai Pegawai } \\
\text { Negeri Sipil. }\end{array}$ & $\begin{array}{l}\text { Penghasilan orang } \\
\text { tua lebih dari Rp. } \\
3.000 .000 \text {. }\end{array}$ & $\begin{array}{l}\text { Jarak rumah ke } \\
\text { sekolah kurang } \\
\text { dari 1 KM. }\end{array}$ & $\begin{array}{l}\text { Siswa ke sekolah } \\
\text { menggunakan } \\
\text { kendaraan pribadi. }\end{array}$ \\
\hline
\end{tabular}

3. Menentukan rating kecocokan setiap alternatif pada setiap kriteria. Rating kecocokan setiap alternatif pada setiap kriteria dinilai dengan 0 sampai 1 seperti pada Gambar 3.

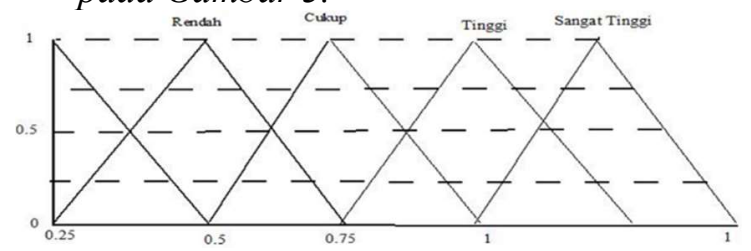

Gambar 3. Himpunan fuzzy untuk derajat kepentingan kriteria

4. Sedangkan tingkat kepentingan setiap kriteria berdasarkan nilai bobot $(W)$, dinilai dengan 0 sampai 1 seperti pada Gambar 4.

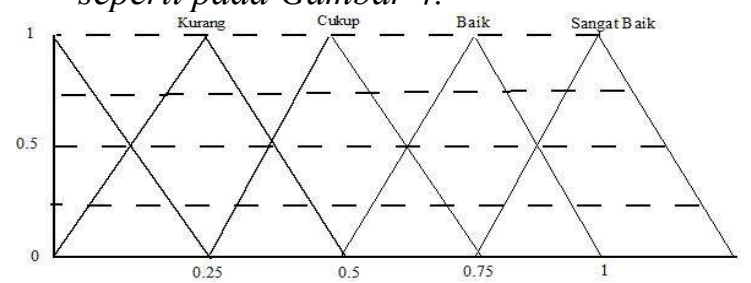

Gambar 4. Himpunan fuzzy untuk derajat kecocokan kriteria

\subsection{Pemilihan}

Pilihan merupakan tindakan pengambil keputusan yang kritis. Fase pilihan adalah fase dimana dibuat suatu keputusan yang nyata dan diambil suatu komitmen untuk mengikuti suatu tindakan tertentu (Turban, et al., 2005). Berikut tahapan pemilihan dengan metode FMADM dengan pengembangan :

1. Representasi masalah

2. Evaluasi himpunan fuzzy

3. Seleksi alternatif optimal

\subsection{Implementasi dan Solusi \\ 3.4.1 Sitemap}

Gambar 5 .

Sitemap sistem dapat dilihat pada

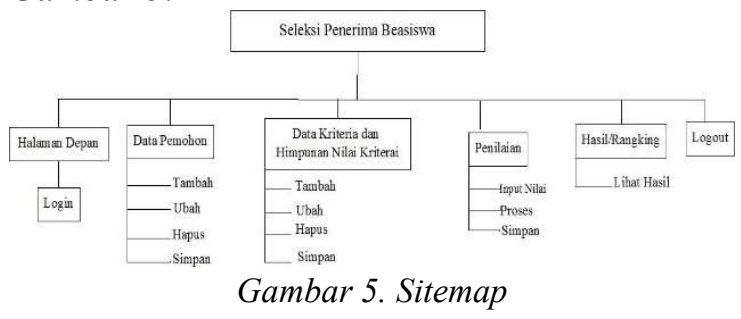

\subsubsection{Data Flow Diagram}

Data Flow Diagram Level 0 dalam penelitian ini dapat dilihat pada Gambar 6.

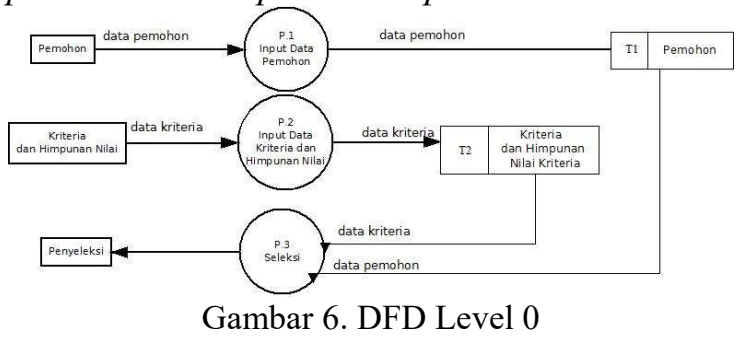

\subsubsection{Database}

Relasi tabel dalam penelitian ini, dapat dilihat pada Gambar 7. 




Gambar 7. Relasi Tabel

\section{PEMBAHASAN}

Contoh hasil perhitungan sistem seperti terlihat pada Gambar 8.

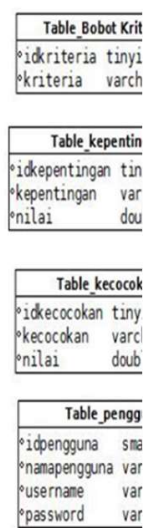

password var



pada Tabel 2, untuk indeks kecocokan setiap altenatif dapat dilihat pada Tabel 3, sedangkan untuk nilai total integral dapat dilihat pada Tabel 4.

Selanjutnya untuk mengetahui siapa yang paling layak mendapatkan beasiswa, maka dilakukan proses pengurutan berdasarkan nilai total integral untuk peringkat penerima beasiswa.

Tabel 2. Tabel Keputusan

\begin{tabular}{|c|c|c|c|c|}
\hline \multirow{2}{*}{ Alternatif } & \multicolumn{4}{|c|}{ Derajat Kecocokan } \\
\hline & Cl & $C 2$ & C3 & $C 4$ \\
\hline$A 1=$ Yuningsih & $K$ & $S B$ & $S B$ & $B$ \\
\hline$A 2=I$ Ketut Rustiana & $B$ & $C$ & $B$ & $K$ \\
\hline A3 $=$ Sasya Lalita Putri & $S B$ & $K$ & $B$ & $C$ \\
\hline A4 $=$ Pilar Avista Lorenza & $B$ & $B$ & $B$ & $K$ \\
\hline A5 = Amelin Fikrilla Pasya & $K$ & $K$ & $S B$ & $S B$ \\
\hline A6 $=$ Intan Kartika & $C$ & $C$ & $C$ & $S B$ \\
\hline$A 7=\operatorname{Ima}$ Ma'isatul Mardiyah & $S B$ & $S B$ & $C$ & $K$ \\
\hline A8 $=$ Adhita Putri Kusuma W.N & $S B$ & $B$ & $C$ & $K$ \\
\hline A9 = Hasbi Bagas Wicaksono & $S B$ & $B$ & $S B$ & $C$ \\
\hline$A 10=M$. Rizki Avib & $C$ & $C$ & $S B$ & $S B$ \\
\hline
\end{tabular}

Tabel 3. Indeks Kecocokan

\begin{tabular}{|c|c|c|c|c|c|c|c|}
\hline \multirow{2}{*}{ Alternatif } & \multicolumn{4}{|c|}{ Rating Kecocokan } & \multirow{2}{*}{\multicolumn{3}{|c|}{ Indeks Kecocokan Fuzzy }} \\
\hline & $C 1$ & $C 2$ & $C 3$ & $C 4$ & & & \\
\hline \multirow{4}{*}{$\begin{array}{l}A 1=\text { Yuningsih } \\
\text { A2 }=\text { I Ketut Rustiana } \\
\text { A3 }=\text { Sasya Lalita Putri } \\
\text { A4 }=\text { Pilar Avista Lorenza }\end{array}$} & $K$ & $S B$ & $S B$ & $B$ & 421 & 375 & 70312 \\
\hline & $B$ & $C$ & $B$ & $K$ & 0.390 & 375 & \\
\hline & $S B$ & $K$ & $B$ & $C$ & 0.421875 & 25 & \\
\hline & $B$ & $B$ & $B$ & $K$ & 0.4375 & 875 & 375 \\
\hline \multirow{6}{*}{$\begin{array}{l}\text { A5 }=\text { Amelin Fikrilla Pasya } \\
\text { A6 }=\text { Intan Kartika } \\
\text { A7 }=\text { Ima Ma'isatul Mardiyah } \\
\text { A8 }=\text { Adhita Putri Kusuma W.N } \\
A 9=\text { Hasbi Bagas Wicaksono } \\
\text { A10 }=\text { M. Rizki Aviv }\end{array}$} & $K$ & $K$ & $S B$ & $S B$ & 0.296875 & 0.4375 & 0.5625 \\
\hline & $C$ & $C$ & $C$ & $S B$ & 0.34375 & 0.46875 & 0.5625 \\
\hline & $S B$ & $S B$ & $C$ & $K$ & 0.515625 & 0.625 & 0.671875 \\
\hline & $S B$ & $B$ & $C$ & $K$ & 0.46875 & 0.5625 & 0.609375 \\
\hline & $S B$ & $B$ & $S B$ & $C$ & 0.546875 & 0.6875 & 0.78125 \\
\hline & $C$ & $C$ & $S B$ & $S B$ & 0.40625 & 0.5625 & 0.6875 \\
\hline
\end{tabular}


Tabel 4. Nilai Total Integral

\begin{tabular}{l|c|c|c}
\hline \multirow{2}{*}{ Alternatif } & \multicolumn{3}{c}{ Nilai Total Integral } \\
\cline { 2 - 4 } & $\alpha=0$ & $\alpha=0.5$ & $\alpha=1$ \\
\hline A1 $=$ Yuningsih & 0.5078125 & 0.578125 & 0.6484375 \\
A2 $=$ I Ketut Rustiana & 0.4375 & 0.4765625 & 0.515625 \\
A3 = Sasya Lalita Putri & 0.46875 & 0.51171875 & 0.625 \\
A4 = Pilar Avista Lorenza & 0.4921875 & 0.53515625 & 0.578125 \\
A5 = Amelin Fikrilla Pasya & 0.3671875 & 0.43359375 & 0.5 \\
A6 = Intan Kartika & 0.484375 & 0.4609375 & 0.515625 \\
A7 = Ima Ma'isatul Mardiyah & 0.5703125 & 0.609375 & 0.6484375 \\
A8 = Adhita Putri Kusuma W.N & 0.515625 & 0.55078125 & 0.5859375 \\
A9 = Hasbi Bagas Wicaksono & 0.6171875 & 0.67578125 & 0.734375 \\
A10 = M. Rizki Aviv & 0.40625 & 0.5546875 & 0.5546875 \\
\hline
\end{tabular}

\section{KESIMPULAN}

Setelah melakukan analisis, implementasi serta pengujian, maka dapat diperoleh kesimpulan bahwa perhitungan pada sistem dengan metode FMADM Dengan Pengembangan yang digunakan mempunyai nilai yang identik dengan perhitungan manual sehingga dapat digunakan sebagai alat bantu pengambil keputusan untuk menentukan penerima beasiswa berdasarkan ketetapan kriteria yang telah ditentukan. lain:

Saran untuk penelitian lanjutan antara

1. Pengembangan lebih lanjut terhadap sistem ini adalah perlu adanya fitur penambahan data kriteria sehingga dapat menangani masalah apabila data kriteria yang ada lebih dari 4 data kriteria.

2. Perlu adanya fitur laporan yang berfungsi untuk menyimpan hasil perhitungan tiap semester sehingga dapat dipertanggung jawabkan oleh pihak yang menggunakan sistem ini.

\section{DAFTAR PUSTAKA}

Harjayanti, J. \& Rozi, A. F., 2016. Sistem Informasi Penilaian Supplier Komputer Menggunakan Metode Fuzzy Multiple Attribute Decision Making Dengan Simple Additive Weighting. Informatics Journal, Volume Vol. 1, No. 3, ISSN : 2503 - 250X, pp. 88-95.

Kusumadewi, S., Hartati, S., Harjoko, A. \& Wardoyo, R., 2006. Fuzzy Multi-
Atribute Decision Making (Fuzzy MADM). Yogyakarta: Graha Ilmu.

Murniasih, E., 2009. Buku Pintar Beasiswa. Jakarta: Gagas Media.

Priatni, C. N. \& Purnomo, A. S., 2017. Sistem Untuk Menentukan Pilihan Pada Program Studi Menggunakan Fuzzy Multiple Attribute Decision Making (FMADM) Dengan Simple Additive Weighting (SAW) (Studi Kasus: POLTEKES Permata Indonesia Yogyakarta). Informatics Journal, Volume Vol. 2, No. 1, ISSN : : 2503 250X, pp. 54-63.

Putra, A. \& Hardiyanti, D. Y., 2011. Penentuan Penerima Beasiswa Dengan Menggunakan Fuzzy Multiple Attribute Decission Making. Jurnal Sistem Informasi (JSI), Volume Vol. 3, No. 1, ISSN Print : 2085-1588, ISSN Online : 2355-4614, pp. 286-293.

Suhendar, A. \& Novia, E., 2014. Sistem Pendukung Keputusan. Jurnal Sistem Informasi, Volume Vol. 1, No.1, ISSN: 24067768, pp. 16-20.

Surya, C., 2015. Sistem Pendukung Keputusan Rekomendasi. Jurnal Rekayasa Elektrika, Volume Vol. 11, No. 4, ISSN. 1412-4785; e-ISSN. 2252-620X, pp. 149-156.

Turban, E., Aronson, J. E. \& Liang, T. P., 2005. Decision Support Systems and Intelligent Sistems (Sistem Pendukung Keputusan dan Sistem Cerdas). Yogyakarta: Andi. 